\title{
ごみ焼却炉環境における溶射皮膜の耐高温腐食性
}

\author{
森本純司 ${ }^{*}$, 山口昭雄 ${ }^{*}$, 山田勝弘 ${ }^{* *}$, 清水重雄 ${ }^{* *}$
}

\section{Hot Corrosion Resistance of Thermal Sprayed Coating in Refuse Incineration Environment}

\author{
Junji MORIMOTO*, Akıo YAMAGUCHI*, Katsuhıro YAMADA** and Shigeo SHIMIZU**
}

Key Words Refuse Incineration Plant, N1-Cr Alloy Coatıng, Detonation Gas Sprayıng, Hot Corrosion Resistant

\section{1. 緒言}

エネルギーの有効利用, 地球環境の問題などによりご み焼却炉プラントの燃焼条件は苛酷になっており，耐熱 性, 耐酸化性に優れた部材が要求されている。しかし, このような燃焼環境における金属材料の高温腐食挙動に ついては発電プラント, ガスタービンなどに比較すると あまり報告されていない。溶射加工法はセラミックおよ び金属の構成成分を微視的に制御し, 各種環境に対応し た保護皮膜を材料表面に形成できる利点並びに保守管理 の簡便性からごみ焼却炉ボイラー伝熱管などの高温腐食 防止皮膜の形成に有効と考えられる ${ }^{1)}$ 。

そこで, 本研究では, ガス爆発溶射法により作製した $\mathrm{N}_{1}-\mathrm{Cr}$ 合金溶射皮膜，自溶合金溶射皮膜のごみ焼却炉 ボイラーへの適用に関して検討する。なお，溶射皮膜の 高温腐食防止機能についてはごみ焼却炉から採取した燃 焼灰を用いて求めた。

\section{2. 実験方法}

被溶射体は, 直径 : $15 \mathrm{~mm}$, 長さ : $50 \mathrm{~mm}$ の棒状に切 り出した炭素鋼 (SS 400) であり, 被溶射面はアルミナ 研削材（\#54）により粗面化処理した。溶射材料は市販 の $80 \mathrm{mass} \% \mathrm{Ni}-20 \mathrm{mass} \% \mathrm{Cr}$ 合金粉末，50mass\% $\% \mathrm{~N}_{1}$ $50 \mathrm{mass} \% \mathrm{Cr}$ 合金粉末および $\mathrm{Ni}$ 基自溶合金粉末 $\left(\mathrm{N}_{1}\right.$ : Bal. Cr : 10 mass \%, B : 2.5mass\%, Fe : 2.5 mass \%, Si : 2.5 mass\%, C : 0.15mass\%) である。溶射 皮膜の作製はガス爆発溶射法により鋼棒の全面に対して 行い，その皮膜厚さは300～350 $\mu \mathrm{m}$ とした。溶射条件は $\mathrm{C}_{2} \mathrm{H}_{2}, \mathrm{O}_{2}, \mathrm{~N}_{2}$ のガス総流量を $6000 \mathrm{~L} / \mathrm{h}$ に設定し，そ の混合比率を $1: 1.2: 0.8$ とした。なお, 比較検討のた めプラズマ溶射法 $\left(\mathrm{Ar}+\mathrm{H}_{2}\right)$ により同じ形状の試験片

* 近畿大学 理工学部 (广577 大阪府東大阪市小若江 3-4-1) Kınkı Unıv. (3-4-1, Kowakae, Higashısaka-shı, Osaka 577)

** 日立造船(株) 生産技術研究センター（二551 大阪府大阪市大 正区船町 2-2-11)

Hitachı Zosen Corp. (2-2-11, Funamachı, Taisho-ku, Osaka-sh1, Osaka 551)
を作製した。高温腐食実験は，ごみ焼却炉ボイラー部か ら採取した燃焼灰（主成分， $\mathrm{Cl} \cdot 15.8 \mathrm{mass} \%, \mathrm{~S}: 641$ mass\%, $\mathrm{Na}: 5.25 \mathrm{mass} \%$, Si $4.36 \mathrm{mass} \%, \mathrm{Al}$ : 4.04mass\%, K : 5 45mass\%, Ca : 17.45\%) および $\mathrm{NaCl}, \mathrm{PbCl}_{2}$ を 5 mass\%, 10mass\%添加した灰に よる全浸せき試験法を採用した。試験温度はごみ焼却中 においてボイラー部分が受けるガス温度に相当する 873 Kに設定し，大気雾囲気に扔いて $20 \mathrm{~h}$ 腐食試験（ $5 \mathrm{~h} \times$ 4 サイクル）を行った。溶射皮膜の腐食防止効果は, 侵 食量の経時変化により求めた。併せて, 腐食実験前後の 溶射皮膜の侵食状態, 物性変化について光学湿微鏡観察, EPMA 分析した。

\section{3. 実験結果および考察}

ガス爆発式溶射法およびプラズマ溶射法による N1$\mathrm{Cr}$ 合金溶射皮膜, $\mathrm{N} 1$ 基自溶合金溶射皮膜の高温腐食実 験結果を図 1 に示す。燃焼灰中における溶射皮膜, 素地 鋼の侵食量は, ほぼ直線則に近い経時変化を示したので, 侵食速度 $(k)$ は $\triangle W=k t$ の直線式 $(\triangle W$; 侵食量, $t$; 試験時間）を適用して求めた。図から認められるよう各

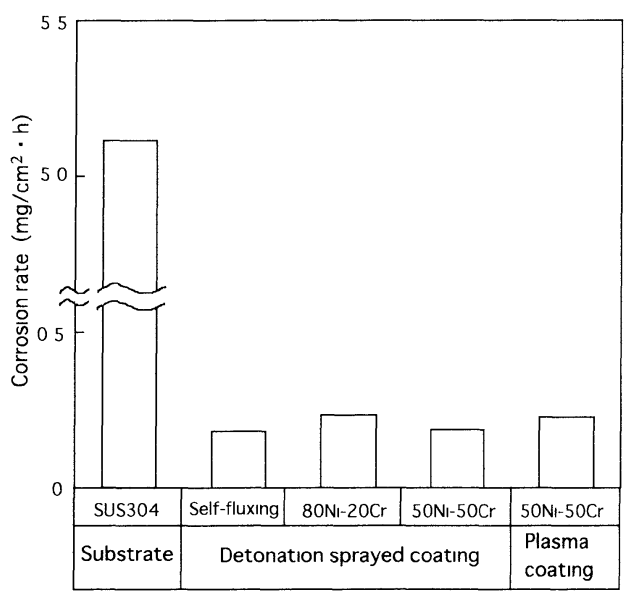

Fig. 1 Hot corrosion rate of thermal sprayed coatings in refuse incineration ash immersion test. 


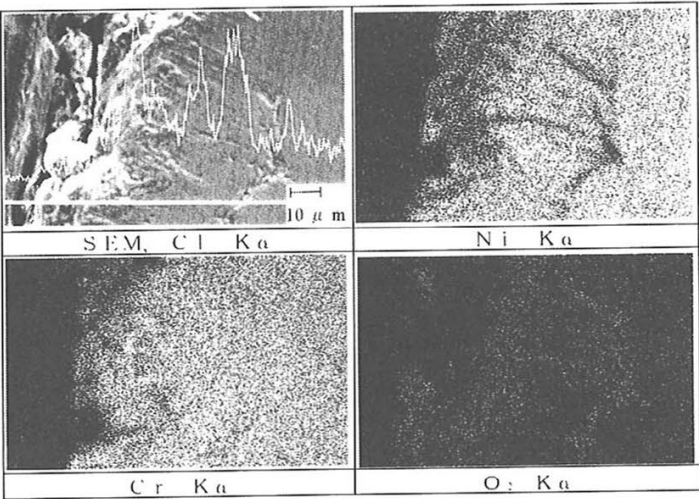

Fig. 2 Result of EPMA analysis of detonation sprayed $50 \% \mathrm{Ni}-50 \% \mathrm{Cr}$ alloy coating tested for $20 \mathrm{~h}$ at $873 \mathrm{~K}$.

溶射皮膜を形成した炭素銅の侵食速度はステンレス鋼 （SUS 304）の約 1/20に減少しており，腐食防止皮膜之 して適用可能と思われる。その中でも50\% Ni-50\% Cr 合金溶射皮膜および $\mathrm{Ni}$ 基自溶合金溶射皮膜の侵食速度 は最す少なくなっており，ごみ燃焼環境における金属材 料の保護皮膜として有効と考えれる。なお，ボイラー伝 熟管の保守管理などの容易性を考慮すると前者の溶射皮 膜が有用である。

ごみ燃焼炬における構造材料の侵食は，一般家庭など から排出される調味料頪、塩素系プラスチック類などに 加えて, 缶詰などの金属類す含まれることから然焼ガス 中の $\mathrm{HCl}$ 並びに燃烧残渣物中に含まれる各種金属塩化 物によって起こると述べられている2゙。そこで，ガス 爆発式溶射法により作製した $50 \% \mathrm{Ni}-50 \% \mathrm{Cr}$ 合金溶射 皮膜についても高温腐食試験後の侵食状態を EPMA 観 察した。図 2 の皮膜断面の元素分析結果加らあ認められ るように皮膜表面部 (約 $10 \mu \mathrm{m})$ では, 塩化物溶融塩と の腐食反応によると想定される $\mathrm{Cl}$ 元素の分布が認めら れる。しかし，溶射皮膜の中心部においては塭素は観察 されておらず Ni-Cr 合金皮膜が素地鋼までの侵食を阻 止している。塩化腐食に対して $\mathrm{Ni} ， \mathrm{Cr}$ などを含む金属 材料か耐食性に優れているのは,これら金属塩化物の融 点が他の金属に比較して高いこと $\left(\mathrm{CrCl}_{3} ; 1423 \mathrm{~K}\right.$, $\left.\mathrm{NiCl}_{2} ; 1273 \mathrm{~K}\right)$ が奇与していると述べられている ${ }^{3)} 。$ $\mathrm{Ni}-\mathrm{Cr}$ 合金溶射皮膜の防食機能が優れているのはこれ らの金属塩化物が表面部に形成されるためと推考される。

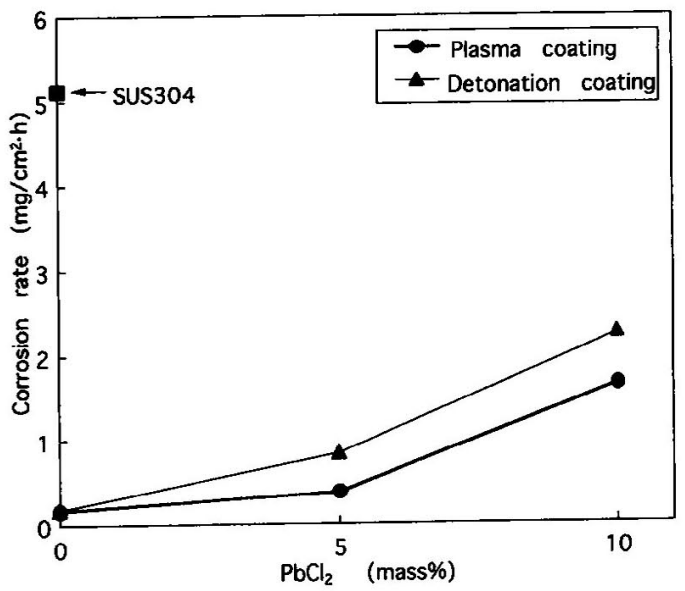

Fig. 3 Relationship between hot corrosion rate of coatings and $\mathrm{PbCl}_{2}$ content in refuse incineration ash.

また, 高温加熱によって皮膜中の積層粒子間に形成され るクロム酸化物も塩素イオンの侵入阻止に寄与したと思 われる。

図 3 は，塩素イオンが $\mathrm{Ni}$ 基自溶合金溶射皮膜の高温 腐食反応に及ぼす影整を明らかにするため採取した燃焼 灰に対して $\mathrm{PbCl}_{2}$ を添加した灰より高温腐食試験した 結果を示した。各溶射皮膜の侵食速度は塩化物含有量の 増加とともに大きくなる傾向を示しており，10mass\% $\mathrm{PbCl}_{2}$ 添加した燃焼灰での各試験片の侵食速度は，採 取した状態のごみ燃焼灰における侵食速度の約 3 倍にな ることが分かった。これらの実験結果は溶射皮膜の耐食 性に対して然焼灰組成が大きく影響することを示唆して いる。

\section{4. 結 論}

ごみ焼却炉から採取した燃焼灰を用いて溶射皮膜の高 温府食防止効果にについて検討した結果, ガス爆発溶射 法による50\% Ni-50\%Cr 合金溶射皮膜および $\mathrm{Ni}$ 基自溶 合金溶射皮膜が耐食性に優れていることが分かった。

(Received May 29, 1997 ; Accepted July 7, 1997)

\section{文献}

1) 高橋孝二, 辻 一郎; 高温学会誌, 16, 277 (1960)

2）基 昭夫, 吉葉正行 ; 防食技術，39，196（1990）

3) 原田良夫 ; 溶射, 33，274 (1996) 